\title{
PENGEMBANGAN PROGRAM PELATIHAN PRA-MAGANG MAHASISWA PROGRAM STUDI BAHASA INGGRIS POLITEKNIK NEGERI JEMBER
}

\author{
Titik Ismailia, Ali Muhtadi \\ Politeknik Negeri Jember, Universitas Negeri Yogyakarta, \\ titikarul@gmail.com, ali_bintangku@yahoo.co.id
}

\begin{abstract}
Abstrak
Penelitian ini bertujuan untuk menghasilkan model program pelatihan pra-magang yang baik dalam meningkatkan kemampuan berkomunikasi mahasiswa program studi Bahasa Inggris Politeknik Negeri Jember (Polije). Jenis penelitian ini adalah penelitian dan pengembangan yang mengadaptasi langkah-langkah Borg and Gall dengan prosedur pengembangan yaitu: studi pendahuluan, perencanaan, pengembangan produk awal, dan pengembangan produk akhir. Produk yang dihasilkan berupa skema pola program pelatihan, buku pedoman pembekalan Praktek Kerja Lapang (PKL), modul dan handout dalam materi reservasi hotel dan pemanduan wisata.
\end{abstract}

Kata kunci: program pelatihanpra-magang, kemampuan berkomunikasi

\section{DEVELOPING PRE-INTERNSHIP PROGRAM OF THE STUDENTS OF ENGLISH STUDY PROGRAM POLITEKNIK NEGERI JEMBER}

Titik Ismailia, Ali Muhtadi

Politeknik Negeri Jember, Universitas Negeri Yogyakarta, titikarul@gmail.com, ali_bintangku@yahoo.co.id

\begin{abstract}
This research aims to produce a good model of pre-internship training program that can enhance the ability on communication skills of the students of English Study Program of Politeknik Negeri Jember. This study was research and development that refers to the model suggested by Borg and Gall with the procedures that were simplified into four steps consisting of: (a) preleminary study, (b) designing, (c) developing early product, and (d) developing final product. The research produced a pattern of model of training program, manual book of pre-internship program, module and handout on hotel reservation and guiding.

Keywords: pre-internship training program, communication skills
\end{abstract}





\section{Pendahuluan}

Program studi (prodi) D3 Bahasa Inggris merupakan salah satu prodi yang ada di Politeknik Negeri Jember (Polije) yang menyelenggarakan pendidikan vokasi setingkat D3 atau ahli madya yang mengarahkan proses belajar mengajar pada tingkat keahlian, keterampilan, dan standar kompetensi yang spesifik sesuai dengan kebutuhan pasar kerja dan stakeholder, serta mempunyai kemandirian dalam berkarya dan berwirausaha berbasis IPTEKS yang diperolehnya. Hal ini sesuai dengan UU Perguruan Tinggi (PT) no 12 tahun 2012 pasal 16 ayat 1 . Sesuai hasil lokakarya kurikulum tahun 2012 prodi ini memiliki target kompetensi lulusan sebagai berikut: (a) menguasai Bahasa Inggris untuk Tujuan Umum, (b) menguasai Bahasa Inggris Untuk Tujuan Khusus (Business $\mathcal{E}$ Correspondence, Hotel \& Restaurant, Tour \& Travel, Secretary, Agrotourism, IT, Banking, (c) menguasai teknik penerjemahan oral dan written (translation), (d) menguasai teknik penerjemahan film (subtitling), (e) mendirikan dan mengelola lembaga kursus bahasa, (f) mendirikan dan mengelola biro perjalanan, (g) menguasai teknik memandu wisata (guiding), (h) menguasai teknik mengelola kegiatan perkantoran, (i) menguasai keterampilan komputer dasar dan bisnis, j) menguasai Public Speaking dan Public Relation, (k) menguasai Bahasa Jepang Dasar. Bidang pekerjaan yang sesuai dengan target kompetensi tersebut adalah sebagai berikut: (a) Staf Hotel Bertaraf Internasional, (b) Staf Perusahaan Asing/Nasional, (c) Staf Perusahaan Export-Import, (d) Pemandu Wisata, (e) Penerjemah Bahasa, (f) Pengelola Biro Penerjemahan, (g) Pengelola/Staf Biro Perjalanan Dalam/Luar Negeri, (h) Pengelola dan pengajar Kursus Bahasa, (i) Master of Ceremony, (j) Penyiar Radio/Televisi, (k) Staf Perbankan, (l) Staf Perusahaan Telekomunikasi.

Mahasiswa juga diwajibkan mengikuti program magang atau Praktek Kerja Lapang (PKL) di semester VI. Lokasi magang disesuaikan dengan peminatan dan kompetensi yang dimiliki mahasiswa seperti hotel berbintang, perusahaan nasional dan multinasional, biro perjalananan wisata, lembaga kursus, LSM (Lembaga Swadaya Masyarakat), dan agrowisata di Bali, Yogyakarta, Malang, dan Jember. Sebelum magang mahasiswa wajib mengikuti program pra-magang yaitu pembekalan yang mempersiapkan mahasiswa menghadapi dunia kerja nyata.

Beberapa konsep pelatihan pramagang telah dilakukan dibeberapa lembaga seperti: Illinois State University dengan program Professional Day model yang dikemukakan oleh LaFolette, dkk (2001, p.18) terbukti mampu meningkatkan keterampilan mahasiswa yang akan magang dan dapat memilih bidang kerja yang sesuai dengan kemampuannya, Delaware Technical and Community College dengan program pelatihan perawat kesehatan di rumah untuk lulusan baru seperti pernyataan Coyle (2011, p.213) pelatihan tersebut terbukti dapat meningkatkan kemampuan dan keterampilan lulusan untuk menjadi perawat yang kompeten dan profesional, dan University of Wollongong, Australia dengan program work-based learning (WBL), work-integrated learning (WIL), dan workrelated learning (WRL) seperti pernyataan Cord dan Clements (2010:pp.28-29) tentang pentingnya mengetahui bidang kerja dan tanggungjawab yang perlu dilakukan sebagai satu langkah sebelum memasuki dunia kerja.

Beberapa penelitian menunjukkan pentingnya pelatihan pra-magang seperti penelitian Beggs, dkk. (2008, pp.34-35) menyatakan bahwa terdapat perbedaan pendapat antara supervisor tentang pentingnya kemampuan dalam memecahkan masalah (problem solving) dan keterampilan berkomunikasi (communication skill) dan pendapat siswa yaitu mempertanggungjawabkan bidang kerja dan teori yang diperoleh di kampus lebih penting. Penelitian oleh Rahim dan Tazijan(2011, pp.45-46) menyatakanperlunya pelatihan Bahasa Inggris untuk front officehotel assistant sebelum menggunakannya di lingkungan kerja. Pe- 
nelitian Oise-Owusu, dkk (2013, p.499) menyimpulkan perlunya pelatihan sebelum magang untuk persiapan praktis siswa dan memberikan kesadaran kepada supervisor untuk lebih memotivasi siswa.

Beberapa kendala masih ditemui berkaitan dengan bidang pekerjaan di lokasi magang seperti: (a) kurangnya pengetahuan tentang soft-skill, dan kesulitan mahasiswa dalam melayani reservasi dengan benar, (b) rendahnya kemampuan mahasiswa dalam melayani pembelian tiket (ticketing), reservasi, dan korespondensi di biro perjalanan, (c) kesulitan mahasiswa memberikan informasi kepada turis yang memiliki latar belakang budaya yang berbeda-beda, ketika menjadi pemandu wisata,(d) kurangnya kemampuan mahasiswa dalam menterjemahkan teks dari Bahasa Indonesia ke Bahasa Inggris untuk publikasi di web, (e) kesulitan dalam menerjemahkan bahasa teknis untuk penyiaran (broadcasting).

Berdasarkan uraian di atas, pembekalan yang memberikan kemampuan dalam praktek nyata di dunia kerja perlu dikembangkan. Beberapa contoh program dapat dipilih oleh lembaga untuk diterapkan dalam memecahkan berbagai masalah yang telah diuraikan diantaranya: model Professional Dayyaitu model yang mempertemukan praktisi dan calon mahasiswa magang untuk dapat berdiskusi dan berlatih tentang satu bidang kerja yang dipilih, model work-based learning (WIL) mengajarkan cara melakukan satu jenis pekerjaan dengan mengintegrasikan latihan ke dalam mata kuliah di kampus, model Home Health Nurse Intership Program yang memberikan pelatihan kepada mahasiswa lulusan keperawatan untuk terlibat langsung dalam pekerjaan sebagai perawat kesehatan dirumah dengan pendampingan dari perawat profesional, dan model Pre-Internship Seminar yaitu program yang memberikan kesempatan kepada mahasiswa untuk berlatih menjadi guru dikelas dengan sesama mahasiswa sebagai siswanya sebelum menjadi guru magang di sekolah yang sesungguhnya.
Dari berbagai jenis model di atas, model Professional Day merupakan model yang dianggap paling sesuai dengan karakteristik siswa dan pembelajaran di kampus Polije yang lebih banyak memberikan kesempatan untuk praktek. Pertimbangan atas pemilihan model yaitu mahasiswa telah terbiasa dengan praktek yang lebih banyak daripada pemberian materi secara teori dan mahasiswa belum pernah bertemu dengan praktisi dalam kegiatan pembelajaran dikelas.

Penelitian difokuskan pada pengembangan program pelatihan pra-magang pada bidang perhotelan khususnya English for Specific Purposes (ESP) reservasi hotel dan pemanduan wisata (tour guiding). Pertimbangan pemilihan kedua materi tersebut antara lain karena: (a) lokasi pelaksanaan magang selama ini berada di hotel dan agrowisata setiap tahunnya, (b) mahasiswa magang ditempatkan sebagai pemandu wisata di lokasi agrowisata, (c) mahasiswa belum dapat melaksanakan pekerjaannya dengan baik, (d) alumni banyak yang bekerja dibidang pariwisata seperti hotel, biro perjalanan wisata, dan agrowisata.

Tujuan dari penelitian ini adalah menghasilkan model program pelatihan pra-magang yang terdiri atas skema pola program pelatihan, buku pedoman pelaksanaan pembekalan PKL, modul, dan handout dalam materi English for Specific Purposes (ESP) yaitu reservasi hotel dan pemanduan wisata. Produk ini dapat meningkatkan kemampuan berkomunikasi mahasiswa. Hasil penelitian yaitu satu set dokumen model program pelatihan pramagang yang terdiri atas: (a) skema pola program pelatihan, (b) buku pedoman pelaksanaan pembekalan Praktek Kerja Lapang (PKL), (c) Modul dalam materi reservasi hotel dan pemanduan wisata, d) Handoutdalam materi reservasi hotel dan pemanduan wisata. Manfaat yang diperoleh dari penelitian ini adalah: untuk mahasiswa, dosen, prodi Bahasa Inggris, dan stakeholders. 


\section{Metode Penelitian}

Penelitian ini menggunakan model penelitian pengembangan Research and Development $(R \& D)$ yang di adaptasi dari langkah-langkah Borg dan Gall yang menghasilkan produk model program pelatihan pembekalan PKL. Langkah-langkah dalam model penelitian ini meliputi studi pendahuluan, perencanaan, pengembangan produk awal, dan pengembangan produk akhir.

Prosedur Pengembangan

Prosedur pengembangan mencakup: (a) studi pendahuluan dengan melakukan analisis kebutuhan yang memotret kegiatan pembelajaran di kelas, kegiatan pembekalan PKL mahasiswa, mekanisme pembekalan PKL di Polije, dan menentukan model pelatihan, (b) perencanaan meliputi menyusun rancangan program pelatihan yang terdiri dari skema program pelatihan, buku pedoman pelaksanaan pembekalan, modul, handout, validasi, dan revisi, (c) pengembangan produk awal meliputi pembuatan pola program pelatihan, buku pedoman pelaksanaan pembekalan PKL, modul, dan handout, validasi oleh ahli kurikulum dan pembelajaran dan ahli materi, uji coba lapangan skala kecil dengan 10 peserta, dan revisi, (d) pengembangan produk akhir mencakup uji coba lapangan skala besar dengan 20 peserta, dan revisi. Produk akhir dari program pelatihan yaitu skema pola program pelatihan, buku pedoman pelaksanaan pembekalan PKL, modul, dan handout yang telah teruji validasinya.

Untuk mengetahui validitas instrumen dan produk digunakan expert judgement dengan content validity yaitu mengevaluasi instrumen dan produk melalui isi dengan meminta penilaian ahli kurikulum dan pembelajaran untuk kualitas model program pelatihan, dan ahli materi untuk keterampilan berkomunikasi sebelum mengujicobakan terhadap subjek uji coba.
Data, Instrumen, dan Teknik Pengumpulan Data

Jenis data yang digunakan adalah data kualitatif diperoleh dari hasil wawancara dengan training manager hotel, pemandu wisata profesional, dan focus group discussion (FGD) dengan dosen pengampu mata kuliah, mahasiswa alumni magang, pada tahap perencanaan, data kuantitatif diperoleh dari hasil evaluasi ahli kurikulum dan pembelajaran dan ahli materi pada tahap validasi produk, hasil evaluasi praktek mahasiswa dan hasil angket pada tahap uji coba. Instrumen penelitian yang digunakan yaitu pedoman wawancara, pedoman observasi, dan angket. Teknik pengumpulan data yang digunakan yaitu metode observasi, wawancara dan angket.

\section{Teknik Analisis Data}

Teknik analisis data untuk hasil wawancara dan FGD menggunakan statistik deskriptif terkait data ke orientasi teoritis yang mendasari model pelatihan, terkait temuan ke dalam studi sebelumnya dan membandingkan konsep, ide, dan teori-teori yang orang lain gunakan untuk membingkai data, implikasi dari temuan untuk membuat program pelatihan (Bogdan \& Biklen, 2007, pp.160-164). Data kuantitatif dari hasil observasi praktek mahasiswa pada tahap uji coba lapangan skala kecil dan besar yang dianalisis menggunakan rubrik penilaian. Data kuantitatif dari angket dianalisis dengan skala 5. Data yang diperoleh dari angket diubah menjadi data interval sebagai berikut: Sangat baik dengan skor 5, baik dengan skor 4, cukup dengan skor 3, kurang dengan skor 2, sangat kurang dengan skor 1. Data angket dianalisis menggunakan skala 5 dengan pilihan: sangat baik (5), baik (4), cukup (3), kurang (2) dan sangat kurang (1). Langkahlangkah dalam analisis data antara lain: a) mengumpulkan data mentah, b) pemberian skor, c) skor yang diperoleh kemudian dikonversikan menjadi nilai dengan skala 5 (Rahman, 2010, p.36). 
Tabel 1. Kriteria Penilaian

\begin{tabular}{cc}
\hline Kriteria & Skor \\
\hline Sangat Baik & $X \geq 5$ \\
Baik & $X \geq 4$ \\
Cukup & $X \geq 3$ \\
Kurang & $X \geq 2$ \\
Sangat kurang & $X \geq 1$ \\
\hline
\end{tabular}

\section{Hasil Penelitian dan Pembahasan}

Hasil penelitian pada tahap studi pendahuluan dalam analisis kebutuhan yaitu berdasarkan pengamatan kegiatan pembelajaran English for Specific Purposes (ESP) yang dilakukan di kelas menunjukkan bahwa dosen telah memberikan materi sesuai dengan silabus dan SAP (Satuan Acara Perkuliahan) yang telah disusun. Contohnya praktek yang dilakukan mahasiswa pada mata kuliah English for Correspondencedengan membuat surat-surat bisnis seperti surat permintaan (inquiry) dan balasannya (reply), penawaran (order letter), surat penanganan komplain (complaint handling). Mata kuliah English for Hotel and Restaurant mahasiswa belajar tentang jenisjenis hotel, cara booking kamar hotel (reservasi), hotel services, restaurant services, table manner, complaint handling, payment, dan mempraktekkan cara reservasi, menjelaskan hotel dan room services, table manner, payment, dan complaint handling.

Hasil pengamatan pada pembekalan PKL yang dilaksanakan menunjukkan bahwa materi yang diberikan berkaitan dengan hal-hal umum yang nantinya akan ditemui dilokasi magang seperti motivasi, kerjasama tim, dan kepercayaan diri. Pemateri berasal dari dosen sendiri dan mahasiswa mendapatkan gambaran tanggung jawab bidang kerja dari alumni dan koordinator. Informasi tentang mekanisme pembekalan di Polije menunjukkan bahwa panitia pembekalan sepenuhnya menyerahkan cara, materi, dan pemateri pembekalan kepada jurusan masing-masing dan memonitor pembekalan dengan menghadiri undangan dan membuka acara tanpa mengetahui alur belajar, materi yang disampaikan, dan pematerinya.

Berdasarkan analisis kebutuhan ditentukan model pelatihan yaitu professional day yang mempertemukan peserta dengan praktisi dibidang perhotelan dan pemandu wisata berlisensi. Pertimbangan pemilihan model yaitu perlunya kegiatan praktek keterampilan yang lebih banyak karena sesuai dengan kegiatan pembelajaran di Polije. Keterampilan yang dibutuhkan untuk melakukan kerja nyata dilokasi magang membutuhkan latihan dan pengawasan dari praktisi untuk meminimalkan mentoring. Materi disesuaikan dengan SOP dan SKKNI.

Hasil pada tahap perencanaan yaitu rancangan draf awal program pelatihan yang terdiri atas skema program pelatihan, buku pedoman pelaksanaan, modul, dan handout. Penyusunan rancangan diawali dengan melakukan wawancara terhadap lima training manager dan HRD (Human Resource Development) hotel-hotel berbintang di Yogyakarta yaitu hotel Sheraton, Shantika, Royal Ambarukmo, Novotel, Grand Aston untuk materi reservasi hotel, dan pengurus dan pemandu wisata profesional dari HPI (Himpunan Pramuwisata Indonesia) Yogyakarta untuk materi pemanduan wisata. Focus group discussion (FGD) dilakukan dengan dosen pengampu mata kuliah dari Polije dan lima orang mahasiswa alumni magang. Hasil analisis wawancara dan FGD menunjukkan bahwa: (1) pengetahuan yang diperlukan untuk reservasi hotel yaitu pengetahuan tentang sistem reservasi, produk hotel seperti kamar dan fasilitasnya, fasilitas hotelnya, harganya, arah menuju hotel, kompetensi berbahasa dan memberikan informasi, SOP reservasi, (2) keterampilan berkomunikasi yang diperlukan untuk reservasi yaitu keterampilan berkomunikasi efektif seperti mendengarkan, berbicara dengan sopan dan senyum, merespon jawaban, dan menulis dengan jelas dan tepat, (3) sikap yang harus dimiliki oleh petugas reservasi dalam berhubungan dengan konsumen karena memberikan pelayanan dan kenya- 
manan baik di hotel maupun dilokasi wisata seperti cara berpakaian, ramah, sopan, (4) menjawab pengetahuan untuk menjadi pemandu wisata yaitu cara memberikan informasi dengan benar, cara berkomunikasi efektif, kemampuan berbahasa, merespon jawaban, memiliki lisensi, pengetahuan tentang SOP tur, (5) keterampilan berkomunikasi yang dibutuhkan untuk menjadi pemandu wisata yaitu public speaking, memberikan informasi praktis dan aplikatif kepada wisatawan tentang objek wisata dan produk wisata, (6) pemandu wisata diharuskan memiliki sikap yang baik dalam berhubungan dengan konsumen yang diatur dalam SOP, (7) diperlukan latihan dengan bidang kerja yang akan dilakukan di lokasi magang berkaitan dengan profesi, kerja nyata, dan kegiatan yang membutuhkan keterampilan secara khusus.

Hasil penyusunan program pelatihan pembekalan PKL dengan model Dick and Carey sebagai berikut: pertama, kompetensi umum yang harus dikuasai oleh peserta pelatihan yaitu mampu melakukan tugas reservasi di hotel dan pemanduan wisata sesuai SKKNI. Kedua, kompetensi umum di bagi menjadi dua kompetensi khusus yaitu untuk reservasi hotel dan pemanduan wisata sesuai dengan SKKNI pariwisata yang diterbitkan dalam peraturan Menteri Tenaga Kerja RI Nomor: Kep. 2/MEN/2/2008 tentang penetapan standar kompetensi kerja nasional Indonesia sektor jasa pendidikan lainnya bidang jasa pendidikan bahasa (pendidikan Bahasa Inggris untuk kepariwisataan) dan Peraturan menteri Tenaga Kerja RI Nomor: Kep.239/MEN/X/2004 tentang penetapan standar kompetensi kerja nasional Indonesia sektor pariwisata subsektor hotel dan restoran. Kompetensi untuk materi reservasi hotel mencakup: memulai percakapan dengan tamu, berkomunikasi di telepon, menjelaskan fasilitas hotel dan kamar, dan menerima dan memproses reservasi. Kompetensi untuk materi pemanduan wisata yaitu mengembangkan dan memutakhirkan pengetahuan industri pariwisata, me- ngembangkan dan memelihara pengetahuan umum yang diperlukan oleh pemandu wisata, memberikan penjelasan sederhana tentang objek dan daya tarik wisata, dan bekerja sebagai pemandu wisata.

Ketiga, analisis instruksional untuk materi reservasi hotel mencakup pengetahuan tentang SOP reservasi, produk hotel, dan langkah-langkah reservasi. Keterampilan yang di butuhkan yaitu mendengarkan, berbicara, menulis, dan sikap yang baik dalam bekerja. Materi pemanduan wisata dengan pengetahuan SOP tur, Cross Culture Understanding (CCU), complaint handling, keterampilan seperti language skills, communication skills, interpersonal skills, dan sikap yang diperlukan yaitu berpakaian rapi, sopan, dan ramah. Keempat, sasaran peserta yaitu mahasiswa semester $\mathrm{V}$ dengan menanyakan peminatan lokasi magang yaitu hotel dan agrowisata dengan karakteristik laki-laki dan perempuan berusia 21-22 tahun dengan jumlah 18 dan 31, berasal dari wilayah Jember dan sekitarnya yaitu Lumajang, Bondowoso, Banyuwangi, Probolinggo, Situbondo, dan Malang. Asal sekolah SMA, SMK, dan kemampuan Bahasa Inggris yang beragam.

Kelima, menyusun kompetensi dasar (KD) dalam GBPP (garis-garis besar program pelatihan) program pelatihan meliputi tujuan instruksional umum (TIU), tujuan instruksional khusus (TIK), pokok bahasan, subpokok bahasan, metode, media, waktu, dan referensi. Materi yang disajikan yaitu: a) komunikasi efektif dalam melakukan reservasi hotel mencakup pengetahuan tentang SKKNI Perhotelan dan Pariwisata, kecakapan dalam Berbahasa Inggris, pengetahuan tentang SOP, keterampilan berkomunikasi, teknik dalam melakukan praktek agar proses dapat berjalan dengan efektif, dinamis, dan partisipatif, b) komunikasi efektif dalam pemanduan wisata mencakup pengetahuan tentang SKKNI pemanduan wisata, kecakapan dalam berbahasa Inggris, pengetahuan tentang kemampuan standar yang dibutuhkan sesuai SOP dalam pemanduan agrowisata, keterampilan dalam memberikan informasi kepada wisatawan. 
Keenam, indikator pencapaian terhadap materi yang diajarkan dengan menilai kemampuan berkomunikasi sesuai kompetensi yang tertulis pada masing-maing bidang.Ketujuh, metode pembelajaran simulasi digunakan dengan membagi peserta ke dalam kelompok yang terdiri dari 2-3 orang untuk berperan menjadi petugas reservasi dan tamu hotel, pemandu wisata dan wisatawan. Kedelapan, bahan ajar yang digunakan modul dan handout. Kesembilan, rancangan program pelatihan terdiri dari skema program pelatihan dengan model professional day, buku pedoman pelaksanaan pembekalan PKL, modul, handout. Rancangan skema pola program pelatihan disajikan pada Gambar 1.

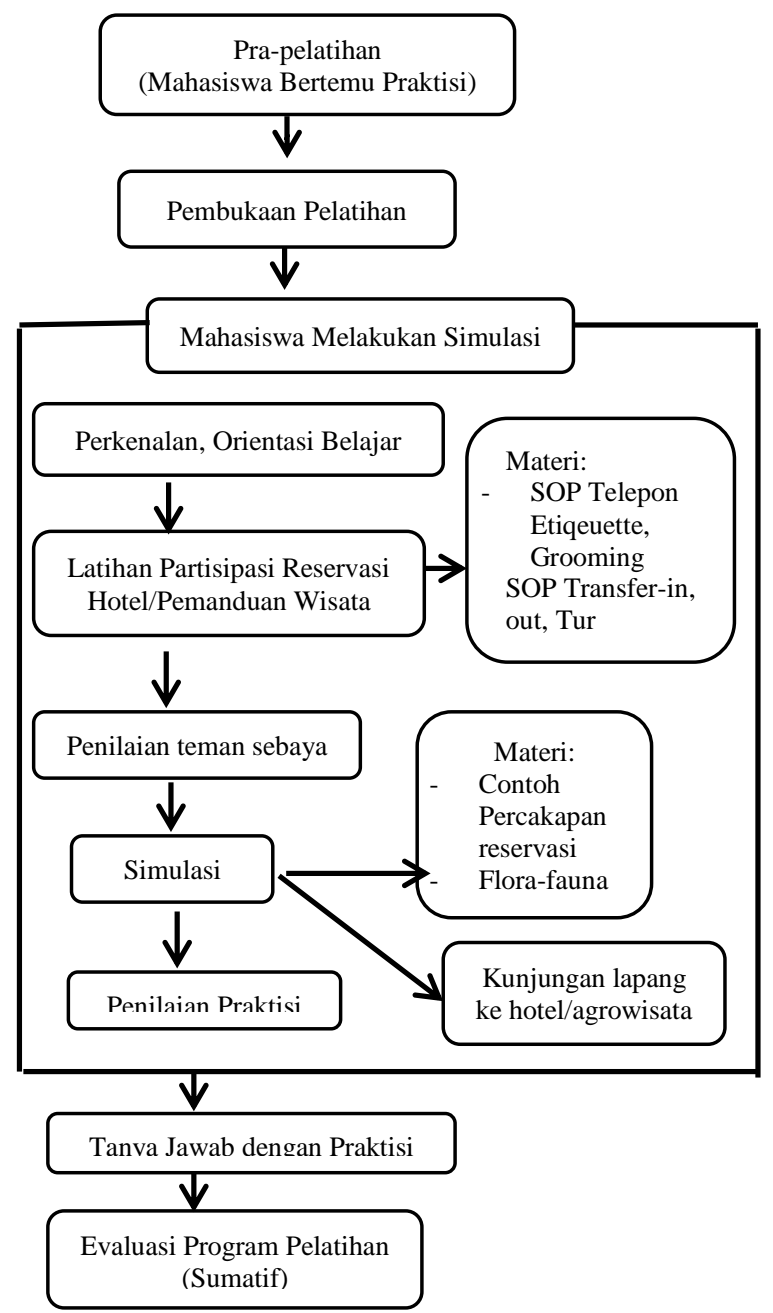

Gambar 1. Skema Rancangan Pola Program Pelatihan Pembekalan PKL
Hasil validasi yang dilakukan dengan meminta komentar dan saran kepada training manager hotel dan pemandu wisata menghasilkan produk awal skema pola program pelatihan pembekalan PKL disajikan pada Gambar 2.

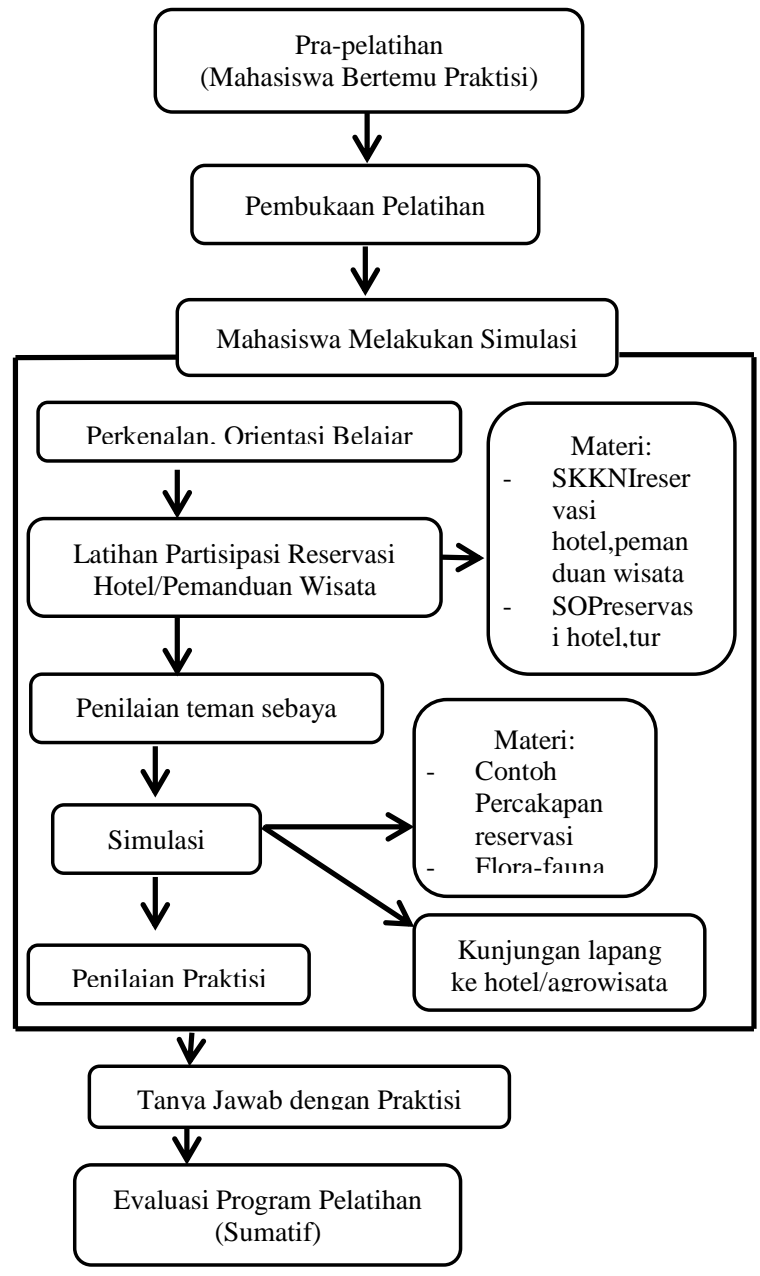

Gambar 2. Skema Pola Program Pelatihan Pembekalan PKL Awal

Gambaran produk buku pedoman pelaksanaan pembekalan PKL terdiri atas gambaran program secara detail meliputi tujuan pelatihan, organisasi pelaksana, metode pelatihan, sasaran peserta, materi dan isi pelatihan, agenda dan waktu pelatihan, dan persiapan pelatihan. Modul terdiri atas: Modul 1 berisi tentang pembukaan, perkenalan, dan orientasi belajar, Modul 2 berisi tentang latihan partisipasi reservasi hotel dan pemandu wisata, Modul 3 berisi tentang pelaksanaan simulasi dan evaluasinya, Modul 4 berisi tentang tanya jawab 
dengan praktisi. Handout berisi materi dalam melayani reservasi hotel dan pemanduan wisata yaitu SOP reservasi dan tur, tata cara berkomunikasi dan bersikap (grooming and hygiene).

Hasil validasi oleh ahli kurikulum dan pembelajaran yaitu Soeharto, Ed.D. dosen Fakultas Teknik jurusan Elektronika yang dilaksanakan pada tanggal 10 November 2014, dan Drs. Sutarto, M.Sc., Ph.D. dosen Fakultas Teknik jurusan Teknik Sipil dan Perencanaan yang dilaksanakan pada tanggal 27 November 2014 di ruang dosen jurusan. Hasil penilaian menunjukkan bahwa hasil bahwa rata-rata penilaian adalah 3,69 dengan kriteria baik. Rekap penilaian ahli kurikulum dan pembelajaran disajikan pada Tabel 2.

Tabel 2. Rekap Penilaian Ahli Kurikulum dan Pembelajaran

\begin{tabular}{|c|c|c|c|c|}
\hline No Aspek Penilaian & Sk & & $\begin{array}{l}\text { Rata- } \\
\text { rata }\end{array}$ & Kriteria \\
\hline $\begin{array}{l}\text { 1. Tujuan } \\
\text { Pembelajaran }\end{array}$ & 4,17 & 3,50 & 3,84 & Baik \\
\hline 2. Isi Materi & 4,33 & 3,83 & 4,08 & Baik \\
\hline $\begin{array}{l}\text { 3. Metode } \\
\text { Pembelajaran }\end{array}$ & 3,67 & 3,33 & 3,50 & Baik \\
\hline $\begin{array}{l}\text { 4. Evaluasi } \\
\text { Pembelajaran }\end{array}$ & 4.00 & 3,00 & 3,50 & Baik \\
\hline $\begin{array}{l}\text { 5. Modul } \\
\text { Pembelajaran }\end{array}$ & 3,80 & 3,60 & 3,70 & Baik \\
\hline $\begin{array}{l}\text { 6. Evaluasi Program } \\
\text { Pelatihan }\end{array}$ & 4,00 & 3,00 & 3,50 & Baik \\
\hline Jumlah & 23,97 & 20,86 & \multicolumn{2}{|c|}{44,23} \\
\hline Rata-rata & & & 3,69 & Baik \\
\hline
\end{tabular}

Saran-saran yang diberikan yaitu: (a) menyesuaikan antara judul tesis, indikator, dan butir-butirnya, (b) butir aspek penilaian dalam bentuk pernyataan, (c) penggunaan kata hubung seperti dan, atau, untuk dalam kalimat, (d) perbaikan layout, konsisitensi antar komponen/isi naskah, (e) penambahan skema kompetensi, rumusan TIK, (f) Modul mahasiswa sebaiknya dipisah dengan pedoman untuk dosen, (g) kemasan buku dibuat praktis dengan ukuran lebih kecil dari A4

Hasil validasi ahli materi oleh Drs. Sulis Triyono, M.Pd. dosen Fakultas Ba- hasa dan Seni jurusan Pendidikan Bahasa Jerman yang dilaksanakan pada tanggal 11 November 2014, dan Drs. Suhaini Muhammad Saleh, MA. dosen Fakultas Bahasa dan Seni jurusan Pendidikan Bahasa Inggris yang dilaksanakan pada tanggal 14 November 2014. Hasil penilaian menunjukkan bahwa rata-rata penilaian 3,69 dengan kriteria baik. Berikut rekap hasil penilaian ahli materi yang disajikan pada Tabel 3.

Tabel 3. Rekap hasil penilaian ahli materi

\begin{tabular}{|c|c|c|c|c|}
\hline No Aspek Penilaian & \multicolumn{2}{|c|}{ Skor } & $\begin{array}{c}\text { Rata- } \\
\text { rata }\end{array}$ & Kriteria \\
\hline $\begin{array}{l}\text { 1. Tujuan } \\
\text { Pembelajaran }\end{array}$ & 4,83 & 4,00 & 4,42 & Baik \\
\hline 2. Isi Materi & 4,50 & 4,17 & 4,34 & Baik \\
\hline $\begin{array}{l}\text { 3. Metode } \\
\text { Pembelajaran }\end{array}$ & 4,00 & 3,67 & 3,84 & Cukup \\
\hline $\begin{array}{l}\text { 4. Evaluasi } \\
\text { Pembelajaran }\end{array}$ & 5,00 & 4,00 & 4,50 & Baik \\
\hline $\begin{array}{l}\text { 5. Modul } \\
\text { Pembelajaran }\end{array}$ & 4,20 & 3,80 & 4,00 & Baik \\
\hline $\begin{array}{l}\text { 6. Evaluasi Program } \\
\text { Pelatihan }\end{array}$ & 4,00 & 4,00 & 4,00 & Baik \\
\hline Jumlah & 26,53 & 23,64 & & 5,10 \\
\hline Rata-rata & & & 4,18 & Baik \\
\hline
\end{tabular}

Saran-saran yang diberikan yaitu: (a) kompetensi isi dan standar kompetensi harus dapat diimplementasikan, (b) mahasiswa harus dapat memahami dan menguasai kompetensi yang ditargetkan, (c) kata asing ditulis miring, (d) tata bahasa, preposisi, kata hubung ditulis dengan benar. Hasil skema pola program pelatihan setelah direvisi disajikan pada Gambar 3.

Uji coba lapangan skala kecil dilaksanakan pada tanggal 28 November 2014 di ruang laboratorium bahasa program studi Bahasa Inggris jurusan Bahasa, Komunikasi, Pariwisata (BKP) Politeknik Negeri Jember. Uji coba ini diikuti oleh 14 peserta dengan rincian materi reservasi hotel 9 orang dan materi pemanduan wisata 5 orang. Peserta pada tahap ini lebih banyak jumlahnya dari yang direncanakan yaitu 10 orang dengan alasan ketertarikan pada program pelatihan yang mempertemukan dengan praktisi dan bidang kerja. Hasil 
penilaian materi reservasi hotel disajikan pada Tabel 4.

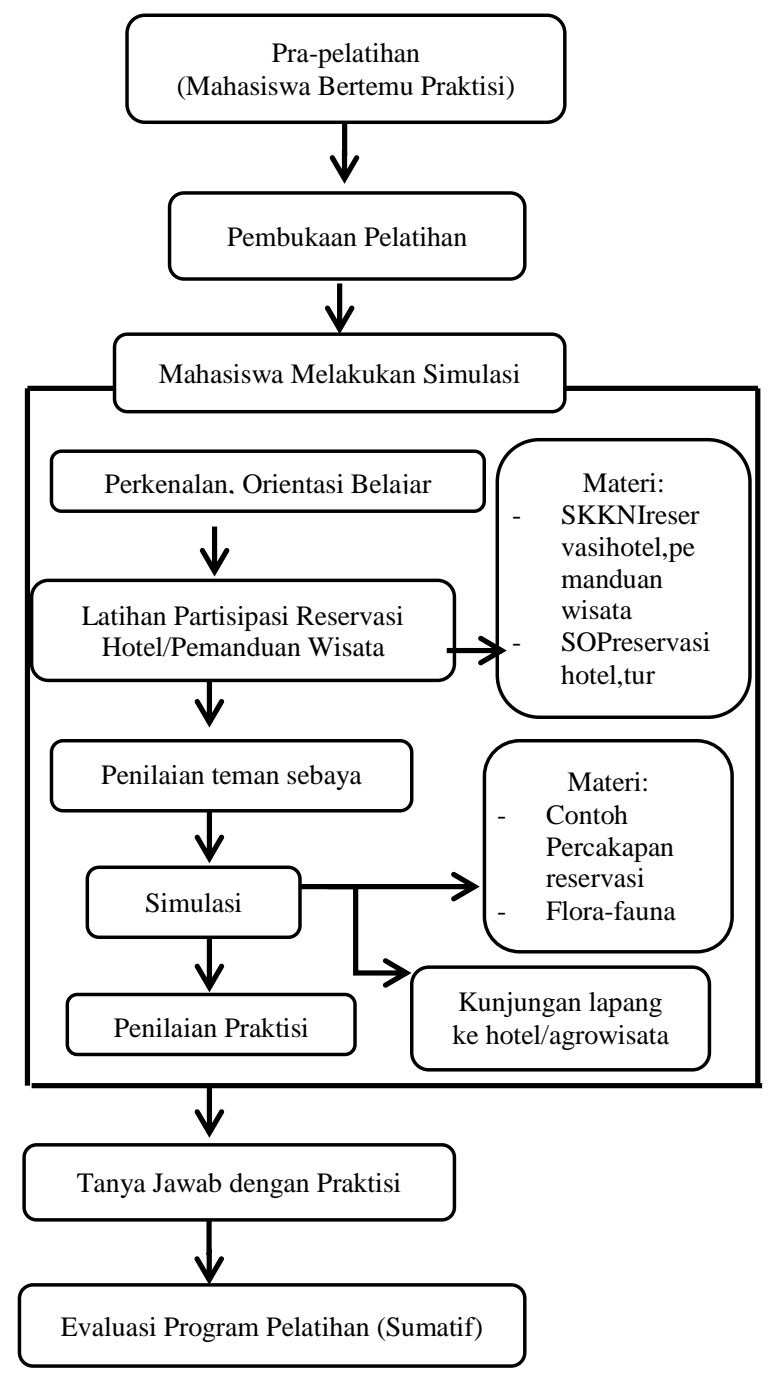

Gambar 3. Skema pola program pelatihan pembekalan PKL

Tabel 4. Rekap hasil penilaian praktek materireservasi hotel

\begin{tabular}{cccc}
\hline No & Nama & Skor & Kriteria \\
\hline 1. & M D A & 11 & Cukup \\
2. & O S & 13 & Baik \\
3. & W N H & 10 & Cukup \\
4. & I L R & 9 & Kurang \\
5. & D A & 10 & Cukup \\
6. & A H & 8 & Kurang \\
7. & K Z & 12 & Baik \\
8. & S H & 13 & Baik \\
9. & Z A S & 8 & Kurang \\
\hline Jumlah & \multicolumn{3}{c}{} \\
\hline \multicolumn{2}{l}{ Rata-rata } & 10,4 & Cukup \\
\hline
\end{tabular}

Tabel 5. Rekap hasil penilaian praktek ateri pemanduan wisata

\begin{tabular}{clcc}
\hline No & Nama & Skor & Kriteria \\
\hline 1. & I Y H & 9 & Sangat Baik \\
2. & F & 7 & Baik \\
3. & M I & 6 & Cukup \\
4. $\quad$ F A & 5 & Cukup \\
5. & E M R & \multicolumn{2}{c}{ Baik } \\
\hline \multicolumn{2}{l}{ Jumlah } & 35 & \\
\hline \multicolumn{2}{l}{ Rata-rata } & 7 & Baik \\
\hline
\end{tabular}

Hasil rekap untuk materi reservasi hotel menunjukkan bahwa peserta yang mendapatkan kriteria baik 3 orang, kriteria cukup 3 orang, dan kriteria kurang 3 orang. Skor total 94 dan rata-rata 10,4 dengan kriteria cukup. Untuk materi pemanduan wisatamenunjukkan bahwa peserta yang memperoleh kriteria sangat baik 1 orang, kriteria baik 2 orang, dan kriteria cukup 2 orang. Skor total 35 dan rata-rata 7 dengan kriteria baik. Hasil angket yang diberikan di akhir program pelatihan adalah baik. Komentar dan saran yang diberikan yaitu: (a) lebih sering bertemu praktisi di bidang perhotelan dan pemanduan wisata, (b) lebih banyak berdiskusi dengan praktisi karena akan menambah wawasan dan pengalaman, (c) lebih sering diadakan pelatihan.

Uji coba lapangan skala besar yang dilaksanakan pada tanggal 5 Desember 2014 untuk materi reservasi hotel dan tanggal 18 Desember 2014 untuk materi pemanduan wisata di ruang laboratorium bahasa jurusan BKP Polije. Peserta berjumlah 13 orang dengan rincian 9 orang untuk materi reservasi hotel dan 4 orang untuk materi pemanduan wisata. Jumlah peserta lebih sedikit dibandingkan uji coba lapangan skala kecil karena waktu yang bersamaan dengan seminar tugas akhir. Pemateri manajer hotel Panorama Jember Bapak Iman Santoso yang telah bbekerja sebagai steward (pramusaji) sejak tahun 1991 di Bali. Hasil penilaian disajikan pada Tabel 6 .

Uji coba skala besar untuk materi pemanduan wisata dengan pemateri Fitri Nur Laily pemandu wisata profesional dan 
tour leader pada PT. Nuansa Tour dan Travel Jember sejak tahun 2013. Hasil penilaian disajikan pada Tabel 7.

Tabel 6. Rekap hasil penilaian praktek materi reservasi hotel

\begin{tabular}{cccc}
\hline No. & Nama & Skor & Kriteria \\
\hline 1. & M D A & 12 & Baik \\
2. & O S & 13 & Baik \\
3. & W N H & 10 & Cukup \\
4. & I L R & 10 & Cukup \\
5. & D A & 10 & Cukup \\
6. & A H & 8 & Cukup \\
7. & K Z & 13 & Baik \\
8. & S H & 12 & Baik \\
9. & Z A S & 8 & Kurang \\
\hline Jumlah & \multicolumn{3}{c}{} \\
\hline Rata-rata & 10,6 & Cukup \\
\hline
\end{tabular}

Tabel 7. Rekap hasil Penilaian Praktek Materi Pemanduan Wisata

\begin{tabular}{cccc}
\hline No. & Nama & Skor & Kriteria \\
\hline 1. & I Y H & 9 & Sangat Baik \\
2. & D A & 8 & Baik \\
3. & M I & 6 & Cukup \\
4. & F A & 8 & Baik \\
\hline Jumlah & 31 & \\
\hline \multicolumn{2}{l}{ Rata-rata } & 7,75 & Baik \\
\hline
\end{tabular}

Hasil rekap pada tabel 6 menunjukkan bahwa peserta yang mendapatkan kriteria baik 4 orang, kriteria cukup 4 orang, dan kriteria kurang 1 orang. Skor total 96 dan rata-rata 10,6 dengan kriteria cukup. Hasil rekap pada tabel 6menunjukkan bahwa peserta memperoleh kriteria sangat baik 1 orang, kriteria baik 2 orang, dan kriteria cukup 1 orang. Skor total 31 dan rata-rata 7,75 dengan kriteria baik untuk materi pemanduan wisata.Saransaran yang diberikan yaitu: (a) pelatihan pra-magang sebaiknya dilakukan jauh hari sebelum pelaksanaan magang, (b) praktek secara langsung sebaiknya dilakukan lebih sering, (c) bertemu praktisi lebih mempersiapkan mahasiswa sebelum magang, (d) sebaiknya mahasiswa lebih menguasai aspek kemampuan berkomunikasi, (e) pemandu wisata perlu dilatih menangani halhal tak terduga yang dapat terjadi pada saat kegiatan tur, (f) mahasiswa perlu berte- mu dengan praktisi. Hasil angket yang diberikan pada akhir uji coba menunjukkan kriteria baik.

Revisi produk sebagai berikut: (a) butir aspek penilaian dalam angket bentuk pernyataan bukan pertanyaan, (b) penggunaan kata hubung seperti dan, atau, untuk dalam kalimat harus tepat, (c) perbaikan layout, dan konsistensi antar komponen/isi naskah, (d) penambahan skema kompetensi, (e) rumusan TIK mengikuti Audience, Behaviour, Content, Degree (ABCD), (f) kata asing ditulis miring seperti handout, verb, preposition harus tertulis handout, verb, preposition, (g) tata bahasa, preposisi, kata hubung ditulis dengan benar, (h) penambahan materi contoh kasus yang ditemui pada saat tur.

Produk model program pembekalan PKL yang telah dikembangkan berisi tentang skema program pelatihan, buku pedoman pelaksanaan pembekalan PKL, modul, dan handout materi reservasi hotel dan pemanduan wisata. Produk ini telah divalidasi oleh ahli kurikulum dan pembelajaran dan ahli materi untuk menjaga kualitas isi secara keseluruhan. Keunggulan produk ini diantaranya model program pelatihan professional days, pembelajaran simulasi, kompetensi yang sesuai SKKNI, modul dan handout dapat digunakan untuk belajar mandiri, memberikan pengalaman dalam bidang kerja reservasi hotel dan pemanduan wisata.

Keterbatasan penelitian ini yaitu: (a)kesulitan dalam mengatur jadwal karena bersamaan dengan waktu perkuliahan dan praktek di kampus, (b) kesulitan mencari ruangan yang memiliki sarana yang sesuai, (c) jumlah mahasiswa yang tidak sama, (d) mencari pemandu wisata berlisensi yang berdomisili di Jember, (e) produk ini belum dapat diuji keefektifannya karena belum ada pelatihan sejenis untuk pembekalan PKL di Polije.

\section{Simpulan}

Kesimpulan penelitian yaitu model program pelatihan pra-magang yang baik 
untuk meningkatkan kemampuan berkomunikasi mahasiswa program studi Bahasa Inggris Politeknik Negeri Jember yaitu professional day model dengan pola: (a) pra-pelatihan, (b) pembukaan pelatihan oleh $\mathrm{p}$ anitia, (c) melakukan simulasi, (d) evaluasi program pelatihan.

Buku pedoman pelaksanaan pembekalan PKL yang dihasilkan mencakup pendahuluan, gambaran umum program, tujuan pelatihan, organisasi pelaksana, sasaran peserta, metode pelatihan, materi dan isi pelatihan, agenda pelatihan, dan persiapan pelatihan. Modul terdiri dari 4 bagian yang masing-masing bagian memiliki jenis kegiatan yang berbeda sesuai urutan simulasi mulai dari perkenalan, latihan, praktek simulasi, dan evaluasi. Handout yang disusun disesuaikan dengan materi reservasi hotel dan pemanduan wisata.

Saran pemanfaatan produk yaitu: (a) bagi mahasiswa sebaiknya mengetahui lebih dulu potensi dan kemampuan diri dalam kemampuan berbahasa, (b) sebaiknya lebih banyak berlatih dengan sesama teman, (c) pertemuan dengan praktisi dapat dimanfaatkan untuk menambah wawasan dan pengalaman, (d) bagi jurusan Bahasa, Komunikasi, dan Pariwisata sebaiknya produk ini digunakan sebagai referensi dalam memberikan pembekalan PKL, (e) sebaiknya memasukkan kompetensi SKKNI pada perkuliahan dan praktek di kelas, (f) sebaiknya mengundang praktisi untuk membantu mengoreksi keterampilan yang telah dimiliki mahasiswa.

Produk ini dapat dijadikan referensi bagi prodi lain untuk membuat program pelatihan yang sesuai dengan kebutuhan dunia kerja. Tentunya diperlukan studi pendahuluan yang berbeda untuk jurusan yang berbeda pula. Produk ini agar bermanfaat sebaiknya disebarluaskan kepada jurusan lain di Polije.

Pengembangan produk lebih lanjut dapat dilakukan dengan bidang kerja yang lain sesuai dengan kebutuhan mahasiswa yang akan PKL atau disesuaikan dengan kebutuhan stakeholder. Selain itu juga harus mempertimbangkan keterampilan yang perlu dilatihkan sesuai dengan SKKNI dari BNSP.

\section{Daftar Pustaka}

Beggs, B., Ross, C.M., Goodwin, B. (2008). A Comparison of Students and Practitioners Perspectives of the Travel and Tourism Internship. Journal of Hospitality, Leisure, Sport and Tourism Education, Vol.7, No.1

Bogdan, R.C, \& Biklen, S.K. (2007). Qualitative research for education an introduction to theory and methods fifth edition. Boston: PearsonEducation, Inc.

Cord, B., \&, Clements, M. (2010, July). Pathway for student self-development: a learning oriented internship approach. Australian Journal of Adult Learning, 50, 2, 287

Coyle, J.S. (July, 2010). Development of a model home health nurse internship program for new graduates: key lessons learned. Journal of Continuing Education in Nursing, p.18806/09-12

LaFolette, S.E., \&, Teresa, B., \& Ronczkowski, P. (2001, Jan/Feb). On the path form student to practitioners: testing the water before the internship, Journal of Environmental Health. 63,6,15.

Osei-Owusu, B., Effah, B., Sam, F.K., et.al. (2013). Student's assessment of internship programme: a case of agriculture education, mampongashanti of university of education, winneba. Journal of Emerging in Educational Research and Policy Studies(JETERAPS),4(3): pp.499-504

Rahman, I., (Sep, 2010). Students' perceptions of effectiveness of hospitality curricula and their preparedness. Thsis Master of Science, unpublished paper, University of Massachusetts Amherst, USA. 